\title{
PATERNALISM, THE MAGISTRACY AND POOR RELIEF IN ENGLAND, 1795-1834
}

When men in the early nineteenth century appealed to the landed proprietors of England to accept their "paternal responsibilities", they gave voice to the conviction that gentry behavior had special relevance for the question of social discipline. ${ }^{1}$ Conservatives, especially, adhered to the view that subordination and the hierarchy of ranks resting upon it constituted the fountainhead of social cohesion. ${ }^{2}$ But at the same time, reliance on this concept of social organization involved the governors in various commitments to their subordinates, for ultimately the cohesiveness of the social order seemed dependent upon the operation of reciprocal obligations. ${ }^{3}$ The place of these imperatives in rural relationships arose from, and contributed to, a tradition that saw the subsistence and wellbeing of the entire community to be dependent upon the social responsibilities of and the connections between the different degrees of interest within the agricultural economy. ${ }^{4} \mathrm{~A}$ characteristic anxiety of the conservative of the period was that the economic individualism of a rising urban and industrial society promised to undermine the social accountability of each component of the social order; this presaged the disintegration of society because the "chain of connexion" between the rich and the poor would thereby be broken. ${ }^{5}$ The implication was that the intrusion of self-

1 See, e.g., Thomas Carlyle, Past and Present (London, 1962; first ed. 1843), pp. 171-72; Robert Southey, "On the Means of Improving the People" (1818), in Essays, Moral and Political (Shannon, 1971), II, pp. 112-13.

2 A. W. Coats, "The Classical Economists and the Labourer", in: Land, Labour and Population in the Industrial Revolution, ed. by E. L. Jones and G. E. Mingay (New York, 1968), p. 106.

${ }^{3}$ See N. Kent, General View of the Agriculture of the County of Norfolk (1769), p. 192.

4 Ibid.; J. P. D. Dunbabin, Rural Discontent in Nineteenth-Century Britain (London, 1974), p. 13.

5 A. Briggs, "The Language of 'Class' in Early Nineteenth-Century England", in: Essays in Labour History, ed. by A. Briggs and J. Saville (London, 1967), pp. 45-46. 
interest, economic or otherwise, threatened a structure of interdependency and mutual respect and concern between ranks. It appeared, then, that the most serious danger to society would certainly come at that point when the landowners of England - the rulers of what still seemed an essentially rural world - abandoned their paternalist traditions and opted for indolence, indifference, or the allures of commercial farming.

Such apprehensions could, of course, be traced further back in time. The Tudor and Stuart periods saw a vast literature decrying the decay among the gentry of "housekeeping", a comprehensive term that included the practice of hospitality, the physical presence of the lord in the manor, and the maintenance of a large and bountiful household. This is to be expected. At no time did the owners of the soil display a consistent regard for the welfare of their inferiors. In addition, in all periods an absentee, a minor, or a politician preoccupied with business at the county or national level might leave a local community unsupported, which could lead to charges of dereliction and recklessness. The fears of nineteenth-century conservatives, however, were built on more substantial foundations, for the eighteenth century had seen what has been called "a crisis of paternalism". ${ }^{6}$ The magnificence of eighteenth-century building, the walls of the great parks, the high box pews in Hanoverian churches, not to mention the stepped-up consolidation of estates through enclosure and economic rationalization, all served to widen the distance between ranks and to compromise the face-to-face interaction that is an essential part of relationships based on deference and subordination. ${ }^{7}$ Sympathy for the poor clearly declined as the gentry increasingly withdrew from social contacts with those in the local communities. The beating of the bounds, the harvest supper, the mummer's performance became more exclusively the activities of the villagers, while the gentry refined their own recreations through the preservation of game, which led to clashes with farmers and the poor who tried to eke out a living by poaching. ${ }^{8}$

But this "crisis of paternalism" has also been taken to include large landowners' wholesale abandonment of their paternal responsibilities, which by the late eighteenth century had apparently degenerated into a mere "theatre of the great". 9 This "illusion of paternalism" primarily consisted of occasional dramatic gestures of benevolence, but involved

${ }^{6}$ E. P. Thompson, "Patrician Society, Plebeian Culture", in: Journal of Social History, VII (1973-74), passim.

7 P. Laslett, The World We Have Lost (New York, 1965), p. 70.

8 B. Kerr, "The Dorset Agricultural Labourer, 1750-1850", in: Proceedings of the Dorset Natural History \& Archaeological Society, LXXXIV (1962), p. 163.

9 Thompson, "Patrician Society, Plebeian Culture", loc. cit., pp. 389-90. 
only minimal responsibilities and outlays in energy. In particular, the period after the outbreak of war with Revolutionary France is offered as "different historical territory" in that it marked the end of all pretense at reciprocity in social relations. ${ }^{10}$ The acute anti-Jacobinism of the gentry, which led them to distrust their subordinates and all efforts to secure popular rights, especially strained the "chain of connexion" between ranks. Above all, it is suggested, by the turn of the century the English landowners and many of the local authorities had adopted the tenets of laissez faire, which struck at the root of paternal responsibilities and substituted the pursuit of self-interest for social accountability as the proper basis for men's actions. ${ }^{11}$ Thus, the paternal relationship had become distinctly one-sided, with the higher ranks continuing to insist on discipline and filial obedience, but no longer willing to reciprocate with a benevolent overlordship. ${ }^{12}$

The problem with such interpretations is that they tend to ignore the extraordinary diversity inherent in a technique of social control that largely relied on personal interaction in a myriad of local communities. In attempting to gauge the extent and nature of paternalistic behavior among the landowners, we are confronted with the need to generalize on the basis of individual acts of benevolence, apathy or outright brutality. Antagonists on this question may be reduced to trading off examples to support their cases, pointing to this landlord here who engaged in building model cottages on his estates, this proprietor there who pulled down cottages to create a "close" parish. One might cite a landlord who used the full measure of the game laws to prosecute famished poachers in hard times, while in the neighboring parish the squire might have encouraged his female relatives to distribute provisions to the hungry poor. Indeed, this latter example is indicative of the complexities involved in making judgements about gentry behavior, for both actions could conceivably have been those of the same man, a man determined at all costs to protect his privileges and pleasures but who, at the same time, was driven by local custom and habit to conform to those legitimizing rituals that encompassed his ideal role as protector of the poor. ${ }^{13}$ What is required to overcome such

10 E. P. Thompson, "The Moral Economy of the English Crowd in the Eighteenth Century", in: Past \& Present, No 50 (1971), p. 129.

${ }^{11}$ Ibid., pp. 129, 131; H. Perkin, The Origins of Modern English Society, 1780-1880 (Toronto, 1972), pp. 182-83, 186-87.

${ }_{12}$ Perkin, op. cit., pp. 182-83, 188; Thompson, "Patrician Society, Plebeian Culture", loc. cit., p. 383.

13 For an instance of the sort, see J. D. Marshall, "Nottinghamshire Labourers in the Early Nineteenth Century", in: Transactions of the Thoroton Society, LXIV (1960), pp. 67-68. 
difficulties is a means of examining the behavior of the gentry, or a prominent part of it, over a period of time in an activity of central importance to those in the local rural communities. In addition, such an activity should allow ample scope for both the working out of paternalistic attitudes or their negation. It is in this respect that a study of the magistracy's administration of the Poor Laws plays a vital role.

Just how significant poor relief was in supporting the agricultural population is difficult to determine. One thing is certain, however: continuing population growth in conjunction with high prices, the decline of some domestic industries, and the abandonment of living-in and yearly hiring practices in favor of day-labor all combined after the 1790's to create a crisis of poverty in large parts of the country. ${ }^{14} \mathrm{~A}$ contemporary survey indicates that 9.7 per cent of the country's population was in receipt of relief in 1831. A break-down of percentages by counties reveals an even greater reliance on the Poor Law system in the South and East, where problems in the arable farming areas were most severe. Here the size of the pauper host might range as high as 14 to 17 per cent of the population, as in the cases of Berkshire, Wiltshire, Essex and Sussex. ${ }^{15}$ Although these figures must be treated with extreme care, recent investigation has generally confirmed the existence of this level of aid dispensation. ${ }^{16}$ One authority has even claimed that during the period between 1817 and 1821 perhaps more than 20 per cent of the entire population received some relief. ${ }^{17}$

What this means in terms of able-bodied pauperism is less clear. We do know that 1795 - a year of exceptionally severe and widespread food shortages and unemployment - marked a permanent alteration in the pattern of poor relief. ${ }^{18}$ Prior to this crisis the parish pension lists were brief and made up chiefly of females, mostly widows, with a smattering of children, invalids and old men. Then quite suddenly the lists lengthened, and the bulk of the new names were male, a situation that remained common right up to the reform of the Poor Laws in 1834. Arable farming's cyclical demand for labor proved to be a chronic problem for relief

14 See E. L. Jones, “The Agricultural Labour Market in England, 1793-1872”, in: Economic History Review, Second Series, XVII (1964-65), pp. 324-26.

15 Tabular Statement Showing the Comparative Ability of the Several Counties in England to Support Their Agricultural Population [Parllamentary Papers (Lords), 1830-31, CCLXXXVIII].

16 See J. D. Marshall, The Old Poor Law, 1795-1834 (London, 1968), pp. 33, 36.

17 J. T. Krause, "Changes in English Fertility and Mortality, 1781-1850", in: Economic History Review, Second Series, XI (1958-59), p. 66.

18 G. W. Oxley, Poor Relief in England and Wales, 1601-1834 (Newton Abbot, 1974), pp. $112-13$. 
authorities. In the cereal-growing counties of the South and East, a Select Committee of 1828 found that from one-fifth to one-twelfth of the ablebodied laborers and their families were assisted from the rates "during several months of the year". ${ }^{19}$ But averaging this dependence over entire counties does not convey a sense of the extent of able-bodied pauperism in some localities. There were many parishes, such as in the South of Wiltshire and parts of Sussex, Kent, Suffolk and Cambridgeshire, where more than half the laboring families regularly received some poor relief during the year. ${ }^{20}$ While it is true that at most periods the majority of laborers were not in receipt of aid, the instability of the labor market in many parts of the country always made the possibility of having to resort to the parish at some time very real for much of the agrarian population. ${ }^{21}$ It was this prospect of unemployment or inadequate wages, as well as the actual existence of such conditions, that explains the laborers' insistence on their right to aid and on the obligation of those in authority to provide sufficient relief.

For the authorities, too, the Poor Laws assumed a special significance. A large part of the formal structure of official paternalism had fallen into desuetude by the end of the eighteenth century. The bench no longer enforced wage rates, and interference with the grain trade and the price of food was confined to crisis years, and then for the most part was undertaken only to assuage the demands of the poor for their customary right to a "fair price". ${ }^{22}$ Only the Poor Laws remained as a shell of the old governmental paternalism. This is what made them so important. Essential not only for the subsistence of the laborers, the administration of relief constituted the ultimate test of the landlords' goodwill in supporting popular expectations and ideals. This was no small matter in a society that to a considerable extent still relied on the rituals of authority and popular patronage as a source of stability. ${ }^{23}$

19 Report from the Select Committee on That Part of the Poor Laws Relating to the Employment or Relief of Able-Bodied Persons from the Poor Rate [PP, 1828, IV], p. 6.

${ }^{20}$ Report from the Select Committee on Poor Rate Returns [PP, 1825, IV], p. 22; E. J. Hobsbawm and G. Rudé, Captain Swing (New York, 1968), pp. 73-74; J. D. Chambers and G. E. Mingay, The Agricultural Revolution, 1750-1880 (New York, 1966), p. 139; N. Gash, "Rural Unemployment, 1815-34", in: Economic History Review, VI (1935-36), pp. 92-93.

21 Marshall, The Old Poor Law, op. cit., p. 37. See C. R. Oldham, "Oxfordshire Poor Law Papers", in: Economic History Review, V (1934-35), p. 94.

22 Thompson, "The Moral Economy of the English Crowd", loc. cit., p. 88; A. J. Peacock, Bread or Blood (London, 1965), pp. 12-13.

${ }^{23}$ See E. P. Thompson, Whigs and Hunters. The Origin of the Black Act (New York, 1975), p. 262. 
The actual operation of the pre-reform relief system, the so-called Old Poor Law, was rooted in England's parishes, where vestries, overseers of the poor, churchwardens, workhouse masters and the occasional medical officer carried out their allotted duties. Nevertheless, the unreformed system provided substantial opportunities for the county magistrates - the major landowners in the rural districts - to direct the administration of relief. It is certainly not true that their intervention was restricted to the exercise of "only appellate jurisdiction". ${ }^{24}$ By the end of the eighteenth century the quarter sessions, through means of committees of justices and a growing executive of salaried officials, had assumed important administrative, supervisory and financial functions. ${ }^{25}$ Since the sessions were not obliged to seek approval for their policies from the Home Secretary or any other higher authority, their discretion concerning affairs within their purview and jurisdictions was limited only by the personal views of the individual magistrates on the county bench. ${ }^{26}$ It was in keeping with the local status of the magistracy that the collective decisions of the quarter sessions on relief matters were promulgated in the form of orders to the overseers. ${ }^{27}$ At times of emergency the intervention of the county bench could be even more immediate and pervasive. In a procedure reminiscent of the 1630 Book of Orders, it was not unknown as late as the early nineteenth century for quarter sessions to divide counties into districts under magisterial committees at whose weekly meetings relief was distributed to the poor. ${ }^{28}$

Corporate responsibility for directing relief administration was often rejected in favor of a more personal control of popular patronage. The primary concern of many magistrates in administering aid was not to maximize their power over wide areas, but to re-affirm their authority in the context of the local community. ${ }^{29}$ This could result in the

24 As is argued in A. Brundage, "The Landed Interest and the New Poor Law: A Reappraisal of the Revolution in Government", in: English Historical Review, LXXXVII (1972), pp. 28, 34.

25 J. R. Poynter, Society and Pauperism: English Ideas on Poor Relief, 1795-1834 (London, 1969), p. 11.

26 C. H. E. Zangerl, "The Social Composition of the County Magistracy in England and Wales, 1831-1887", in: Journal of British Studies, XI (1971-72), p. 114.

27 J. D. Chambers, Nottinghamshire in the Eighteenth Century (New York, 1966), pp. 73-74; S. and B. Webb, English Poor Law History, Part I: The Old Poor Law (Hamden, Conn., 1963), p. 181; M. D. Neuman, "A Suggestion Regarding the Origins of the Speenhamland Plan", in: English Historical Review, LXXXIV (1969), p. 321.

28 Minutes of Evidence Taken Before the Lords Committee Appointed to Consider of the Poor Laws [PP (Lords), 1817, LXXIV], p. 91. 
landlords assuming an even greater, more direct dominance over the relief machinery. Throughout the country, magisterial policy was enforced by means of a rough-and-ready organization of local petty sessions, consisting of two or three justices who met informally to supervise the parish officers. ${ }^{30}$ The local sessions appointed, or at least approved, the overseers of the poor, who were then subject to the bench's direction even in the assessment of the rates. ${ }^{31}$ In a manner similar to quarter-sessional procedure, local gatherings of justices often prescribed by standing order the method of relief administration to be followed in the parishes under their jurisdiction. ${ }^{32}$ The essence of such a system of administration was that the large proprietors, in the guise of magistrates, remained independent within their localities of larger jurisdictional entities, including the quarter sessions, whose decisions the individual justices did not always regard as binding. ${ }^{33}$ There was, consequently, seldom any consistent or uniform relief policy enforced throughout any county for long. ${ }^{34}$

Because of this freedom from outside authority, the proprietors might dispense with even the pretense of legality in administering relief. The justices under the Old Poor Law repeatedly ignored statutes limiting the control of the bench to specific aspects of administration, and private meetings of local magistrates often proceeded without compunction to formulate extra-legal, and even illegal, policies pertaining to the amelioration of distress. ${ }^{35}$ The formalities designed to ensure that the ratepayers' views and those of their officers were at least heard at the policy-making level were likewise sometimes not observed. ${ }^{36}$ So complete

29 See below, p. 387.

30 First Annual Report of the Poor Law Commissioners for England and Wales [PP, 1835, XXXV], pp. 4-5; W. E. Tate, The Parish Chest (Cambridge, 1960), pp. 228-29; G. E. Fussell, Village Life in the Eighteenth Century (Worcester, n.d.), pp. 24, 26; F. G. Emmison and I. Gray, County Records (London, 1967), p. 16; E. M. Hampson, The Treatment of Poverty in Cambridgeshire, 1597-1834 (Cambridge, 1934), pp. 228, 231; Poynter, Society and Pauperism, op. cit., p. 11.

31 Report on Poor Rate Returns, 1825, p. 22.

32 Report from the Select Committee on Labourers' Wages [PP, 1824, VI], p. 23; Report of the Poor Law Commissioners on the Continuance of the Poor Law Commission [PP. 1840, XVII], p. 12; M. E. Rose [Ed.], The English Poor Law, 1780-1930 (Newton Abbot, 1971), p. 57.

${ }^{33}$ See, e.g., Report from the Select Committee on the Poor Laws [PP, 1817, VI], pp. 90. 111.

34 S. and B. Webb, The Old Poor Law, op. cit., p. 426.

${ }_{35}$ First Annual Report, pp. 4-5; Hampson, The Treatment of Poverty, op. cit., p. 228.

36 Minutes of the Lords Committee, p. 65; S. and B. Webb, The Old Poor Law, pp. 168-69. Rates were levied on occupiers rather than owners; therefore, the magistrates, being part of the rentier class, did not pay rates commensurate with their holdings. Onerous rate burdens on tenants, however, could necessitate reductions in rent. 
was magisterial control in some districts that even when justices were aware that the enforcement of their policies went beyond their legal authority, they were not always deterred from insisting on the parish officers' compliance. $^{37}$

Even where select vestries were established under the provisions of the Vestry Acts of 1818 and 1819, which were designed to induce economy in parish expenditure by restricting the intervention of the bench, the justices often remained unhampered in their activities. Although it required at least two magistrates to void a select vestry's decision, authority was given to one justice to order relief in cases of urgent need, the definition of which the magistrate himself determined ${ }^{38}$ The outright refusal of some magistrates to justify their orders for relief rendered these measures equally ineffective.$^{39}$ Complaints received by the House of Commons in the 1820's from parishes in Lincolnshire, Oxfordshire, Shropshire, Somersetshire, Durham, Cornwall and the North Riding attest to the ability and inclination of justices to dictate the relief policy of many select vestries. ${ }^{40}$ The magistrates' successful opposition in the same period to even the establishment of such bodies in Northamptonshire, Nottinghamshire, Somersetshire and Cambridgeshire reveals even more dramatically the power of the justices to counter parochial attempts to control relief policy through the administration of ratepayers in select vestries. ${ }^{41}$

The appellate jurisdiction of the magistrates - what an 1828 committee called "an indirect but effectual power" 42 - also provided the bench with a considerable and far-ranging means of directing parochial administration. Under the Old Poor Law, the responsibility of the landowners to ensure the laborers' subsistence was recognized in the right of the poor to appeal to the bench against the relief decisions of the overseers and the ratepayers in vestries. ${ }^{43}$ Since the appellate procedure could involve onerous duties for the overseers, such as the need to travel many miles to the nearest magistrates to justify their actions, the appeals of the paupers were many times

37 Report on Labourers' Wages, p. 35.

38 Report on Able-Bodied Persons, p. 5. Since the justices acted most often in petty sessions, such limitations were not usually relevant in any event.

39 Report on the Administration of the Poor Laws, Appendix B 1: Answers to Rural Queries, Pt IV [PP, 1834, XXXIII], p. 73d; Report from the Select Committee on Poor Rate Returns [PP, 1822, V], p. 8; Report from the Select Committee on Poor Rate Returns [PP, 1824, VI], p. 19.

40 Report from the Select Committee on Poor Rate Returns [PP, 1823, V], pp. 16, 17; Report on Poor Rate Returns, 1822, p. 29; 1824, pp. 19, 29-30; 1825, pp. 17, 21 .

41 Report on Poor Rate Returns, 1823, pp. 17-18; 1825, p. 21 ; Hampson, The Treatment of Poverty, p. 246.

42 Report on Able-Bodied Persons, p. 4.

43 Ibid., p. 5. 
conceded by default. ${ }^{44}$ In other cases, the poor were able to extract more generous relief from the overseers by merely threatening to take them before the bench, either because of their reluctance to confront the justices or the propensity of the magistrates to override the parish officers. ${ }^{45}$ The result was that overseers tended to anticipate probable orders from the local justices without the bench having to intervene formally. ${ }^{46}$

The justices' appellate jurisdiction was such a highly potent means of intervention because its utilization extended beyond parish boundaries and was not confined to the range of the magistrates' immediate personal influence. ${ }^{47}$ A Royal Commission survey of 1832 shows that even populous rural centers lacking a major landowner, the so-called open parishes, were not outside the reach or concern of the bench. ${ }^{48}$ One of the chief complaints voiced in the replies to the survey was that magistrates residing at a distance controlled parochial administration through the issuance of orders on appeal or the threat of calling the overseers before them. It only required a readiness among the poor of the open parishes to resort to the neighboring justices in order to bring the parochial authorities into line with the surrounding proprietors' views on relief administration. In some instances, an actual appeal did not even have to be granted, the overseers conforming to what was taken to be magisterial policy on the basis of other parishes' experience with justices in the district. ${ }^{49}$

\section{III}

It had not always been necessary for the bench to ply such authority in relief administration. After surmounting the initial difficulties of establishing a compulsory distribution of aid to the indigent in the early seventeenth century, the justices were able to relinquish the details of daily management. Administration settled into a routine based on precedent and custom and became fixed in the parochial structure. ${ }^{50}$ The period from

44 Report on the Poor Laws, 1817, p. 23; S. and B. Webb, The Old Poor Law, p. 162.

45 Report on Poor Rate Returns, 1823, p. 18; Minutes of the Lords Committee, 1817, p. 88; The Poor Law Report of 1834, ed. by S. G. and E. O. A. Checkland (Harmondsworth, 1974), Introduction, p. 37.

46 Report on Able-Bodied Persons, p. 22; S. G. and E. O. A. Checkland, ibid.

47 Minutes of Evidence of the Select Committee of the House of Lords Appointed to Consider of the Poor Laws [PP (Lords), 1830-31, CCLXXXVII], pp. 3, 58-59; Richard Earle to Poor Law Commissioners, 25 June 1836, Second Annual Report of the Poor Law Commissioners for England and Wales [PP, 1836, XXIX], Appendix B, No 15, p. 387; Report on Able-Bodied Persons, p. 55.

48 See Answers to Rural Queries, Pt IV, qq. 43 and 44, passim.

49 Report on Able-Bodied Persons, p. 28; First Annual Report, p. 12.

50 Oxley, Poor Relief, op. cit., pp. 31-32, 53. 
1660 to the 1790 's was, above all, the era of parish management, the overseers and vestries dealing with the social and economic problems arising from the need to relieve, employ and discipline the poor. ${ }^{51}$ Throughout the greater part of the eighteenth century, the justices tended to restrict their interference to only occasionally granting an appeal for more aid ${ }^{52}$ This is what makes the 1790 's a real watershed in the history of Poor Law administration, for after that decade magistrates in large numbers moved to control directly relief distribution in order to avert intolerable economic pressure on the poor.

There is a need here, of course, to determine as nearly as possible the actual extent of magisterial meddling in the early nineteenth century. Thanks to the famous Royal Commission of Inquiry which sat from 1832 to 1834 such a task is not entirely unrealistic, for this body collected some rather extensive evidence of magisterial activities. In 1832 the Commissioners drew up a set of queries which was distributed to selected rural relief officials. Replies were received from more than 10 per cent of the 15,000 parishes in England and Wales, representing approximately 20 per cent of the entire population. Fortunately, question 43 of that circular was directed to the issue that concerns us here. Local authorities were asked: "Is Relief or Allowance generally given in consequence of the advice or order of the Magistrates, or under the opinion that the Magistrates would make an Order for it if application were made to them?" 53 A compilation of the answers that the Commission received is found on pp. 382-83.

Before evaluating this tabulation certain points should be clarified. Because the respondents were free to answer as they pleased, the replies were often ambiguous or irrelevant, and it was not unusual for the question to go unanswered altogether. Of the 1,170 English parishes responding to the survey, 386 did not answer the question or made an irrelevant reply; these responses have not been taken into consideration in computing the percentages in columns 6, 7 and 8 of the tabulation. Also, it is not clear on what basis the reporting parishes were selected, so it must not be assumed that they represent a random sample of all rural parishes. On the other hand, there is no suggestion that the reporting parishes were chosen with any special criteria in mind, and despite the shortcomings of the survey it does provide a valuable glimpse into relief administration in a large

51 E. W. Martin, "From Parish to Union: Poor Law Administration, 1601-1865", in: Comparative Development in Social Welfare, ed. by E. W. Martin (London, 1972), p. 31. 52 A. W. Ashby, One Hundred Years of Poor Law Administration in a Warwickshire Village (Oxford, 1912), p. 40; Hampson. The Treatment of Poverty, p. 225; Thompson, "Patrician Society, Plebeian Culture", p. 90.

53 Answers to Rural Queries, Pt IV, q. 43. 
number of parishes. ${ }^{54}$ This may be seen from a break-down of the replies to question $\mathbf{4 3}$ for the whole of England: 488 parishes reported that relief was distributed according to the directions of the justices, 235 that it was not, and 61 that the bench sometimes interfered.

Even if these results only just approximate reality, they are a significant indication that by 1832 the English magistrate was no stranger to the operation of the Poor Laws. In 66 per cent (27) of the 41 counties and ridings the bench directly controlled relief policy in half or more of the reporting parishes. In 34 per cent (14) of the counties and ridings the magistrates dictated policy in two-thirds or more of the parishes making returns. Only in 29 per cent (12) of the counties and ridings were half or more of the reporting parishes entirely free from such interference. It should be noted that these figures include counties in the West Midlands and the North where there was a particularly low level of intervention, the West Riding being an interesting exception. If attention is confined to the Southern and Eastern districts, the area of the country suffering from the most acute agrarian distress, a much more impressive indication of magisterial activity is found. In some counties, such as Sussex, Buckinghamshire, Essex, Oxfordshire, Northamptonshire, Wiltshire, Berkshire, Huntingdonshire, Hampshire, Dorsetshire, Surrey and Somersetshire, all recording "yes" replies of over 70 per cent, the bench seems to have virtually monopolized parochial administration. Clearly a pattern of intervention based on the degree of rural distress emerges from the tabulation. It will be noticed that the counties listed in the table are ranked according to poor-relief expenditure for 1831, with the most burdened county, Sussex, appearing at the head of the chart (see column 5). In the first 21 counties listed, 18 record unequivocal magisterial interference in half or more of their reporting parishes, while in the next 20 counties listed, only 9 record a similar level of magisterial activity (see column 6). This suggests that the justices were most heavily involved in the administration of relief in those districts where the pressure of poverty and the burden on the rates were greatest, deteriorating conditions for the poor most often prompting magisterial action.

It may be that the Swing riots of 1830 in Southern and Southeastern England had led to an increased need to show interest in the welfare of the laborers in those areas. But it would be a mistake to view these disturbances as an isolated event, producing a unique flurry of concern among the

54 Professor Mark Blaug has used this same survey as the basis for some significant conclusions regarding relief practices prior to 1834. See "The Poor Law Report Reexamined", in: Journal of Economic History, XXIV (1964), pp. 229-45. 


\begin{tabular}{|c|c|c|c|c|}
\hline & 1 & 2 & 3 & 4 \\
\hline Counties & $\begin{array}{l}\text { Total } \\
\text { number } \\
\text { of rural } \\
\text { parishes }\end{array}$ & $\begin{array}{l}\text { Percentage } \\
\text { of rural } \\
\text { parishes } \\
\text { reporting }\end{array}$ & $\begin{array}{l}\text { Total county } \\
\text { population } \\
\text { in } 1831 \text { (in } \\
\text { thousands) }\end{array}$ & $\begin{array}{l}\text { Percentage } \\
\text { of popula- } \\
\text { tion report- } \\
\text { ing }\end{array}$ \\
\hline Sussex & 313 & 27 & 275 & 69 \\
\hline Bucks. & 230 & 16 & 148 & 23 \\
\hline Suffolk & 525 & 10 & 299 & 20 \\
\hline Essex & 413 & 12 & 321 & $3 !$ \\
\hline Oxford & 298 & 10 & 154 & 42 \\
\hline Beds. & 141 & 12 & 96 & 12 \\
\hline Northants. & 343 & 5 & 181 & 9 \\
\hline Wilts. & 374 & 8 & 243 & 20 \\
\hline Berks. & 222 & 16 & 147 & 27 \\
\hline Norfolk & 753 & 6 & 394 & 10 \\
\hline Hunts. & 107 & 13 & 54 & 18 \\
\hline Kent & 421 & 13 & 484 & 25 \\
\hline Hants. & 342 & 16 & 318 & 31 \\
\hline Cambridge & 169 & 25 & 145 & 34 \\
\hline Herts. & 147 & 13 & 145 & 23 \\
\hline Yorks. (E.R.) & 365 & 3 & 206 & 5 \\
\hline Leicester & 339 & 5 & 199 & 12 \\
\hline Dorset & 305 & 5 & 161 & 7 \\
\hline Hereford & 274 & 7 & 112 & 13 \\
\hline Lincoln & 727 & 3 & 321 & 6 \\
\hline Surrey & 146 & 18 & 491 & 12 \\
\hline Middlesex & 80 & 1 & 1,373 & 0.6 \\
\hline Westmorland & 116 & 17 & 56 & 5 \\
\hline Warwick & 255 & 15 & 340 & 26 \\
\hline Devon & 475 & 5 & 500 & 6 \\
\hline Somerset & 493 & 5 & 409 & 16 \\
\hline Yorks. (N.R.) & 537 & 2 & 193 & 5 \\
\hline Gloucester & 425 & 7 & 391 & 18 \\
\hline Shropshire & 275 & 7 & 225 & 23 \\
\hline Worcester & 241 & 8 & 214 & 49 \\
\hline Durham & 297 & 13 & 257 & 49 \\
\hline Cornwall & 212 & 15 & 304 & 19 \\
\hline Derby & 331 & 2 & 240 & 0 \\
\hline Notts. & 269 & 10 & 228 & 27 \\
\hline Stafford & 345 & 4 & 415 & 13 \\
\hline Cheshire & 500 & 3 & 338 & 2 \\
\hline Northumb. & 524 & 4 & 181 & 13 \\
\hline Yorks. (W.R.) & 666 & 9 & 987 & 36 \\
\hline Cumberland & 294 & 16 & 127 & 26 \\
\hline Lancashire & 444 & 4 & 1,352 & 4 \\
\hline
\end{tabular}

Note: Rutland is not included because none of its reporting parishes (4) replied to q. 43. 


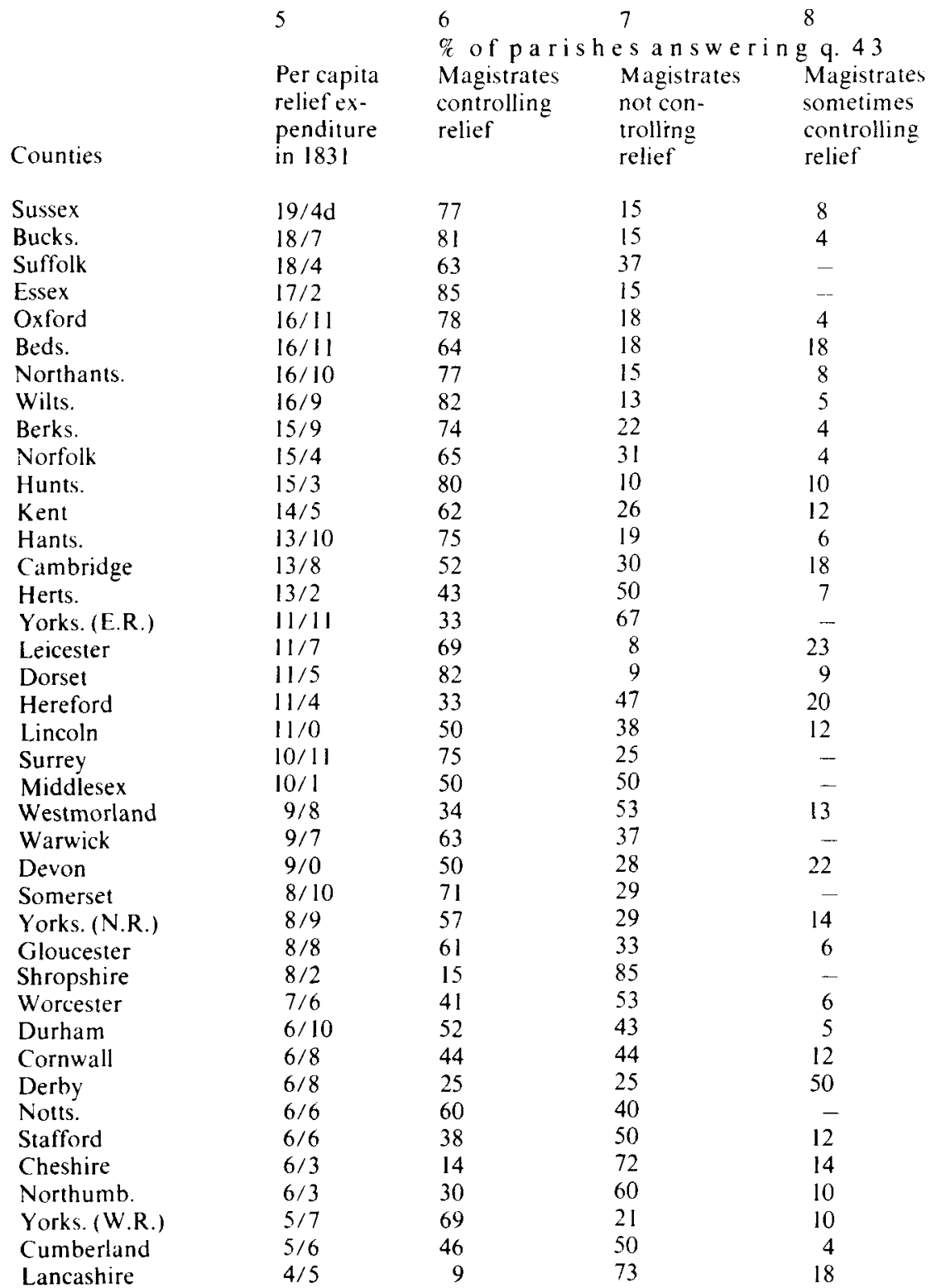

Source: Blaug. "The Poor Law Report Reexamined" (cf. note 54), pp. 236-37, for columns 1-5: Answers to Rural Queries. Pt IV (cf. note 39), for columns 6-8. 
gentry. The general tumults of 1795 and 1800-01, the East Anglian risings of 1816 and 1822, and the increase in rural crime and sporadic violence after 1815 showed clearly enough over a long period of time the depth of the crisis of poverty and the need for the authorities to act. ${ }^{55}$ The rash of parliamentary investigations of the Poor Laws that followed the French Wars reveals an unmistakable determination among the justices to secure control of the increasingly important administration of the Poor Laws. A Select Committee in 1828 noted that "in many counties, [...] especially throughout the South of England", the justices had assumed the responsibility of directing relief administration. particularly as it affected the able-bodied poor and their families. ${ }^{56}$ The reports of other bodies in the years leading up to 1828 give substantial support for such a claim, Select Committees in $1822,1823,1824,1825$ and 1826 finding that the bench was active in intruding in to parochial affairs. ${ }^{57}$

The rapid spread after 1795 of the allowance system, a method of wage subsidization from the poor rates commonly known as the Speenhamland Plan, also indicates the degree to which the bench had become involved in relief administration. for this technique of aid dispensation was nearly always associated with sessional decisions. Allowances in aid of wages appear to have had their greatest vogue during the Napoleonic Wars. with a decline in their use setting in after high wartime grain prices had collapsed. ${ }^{58}$ Notwithstanding this, Select Committees found evidence of the continued use of the allowance system in parts of Suffolk, Sussex, Bedfordshire, Buckinghamshire, Dorsetshire, Wiltshire, Norfolk, Huntingdonshire, Devonshire, Kent, Hertfordshire, Hampshire, Surrey, Essex, Cambridgeshire, Middlesex. Berkshire and Oxfordshire as late as $1828 .{ }^{59} \mathrm{It}$ should be stressed, however, that the intervention of the magistrates in these years was not confined to the mere adoption of allowance scales in sessional meetings. A significant point of the 1832 survey is that even at the

i5) Hobsbawm and Rudé, Captain Swing. op. cit., pp. 77-80.

56 Report on Able-Bodied Persons. p. 4.

57 Report on Poor Rate Returns, 1822, pp. 28, 38: 1823.pp. 27-29: Report on Labourers' Wages, p. 6: Report on Poor Rate Returns, 1825. p. 20: Report from the Select Committee on Poor Rate Returns [PP. 1826. III]. pp. 17-18.

is Blaug. "The Poor Law Report Reexamined". loc. cit., p. 231: id.. "The Myth of the Old Poor Law and the Making of the New". in: Journal of Economic History. XXIII (1963). pp. 159. 166. On the other hand, a recent study by D. A. Baugh suggests that the bench may well have been engaged in extending, rather than abandoning. the use of allowance scales in the years after the war. "The Cost of Poor Relief in South-East England. 1790-1834", in: Economic History Review, Second Series. XXVIII (1975). p. 64.

:59 Report on Labourers' Wages. p. 5: Abstract of Returns Made to the Committee in 1824 Relative to Labourers' Wages [PP. 1825, XIX]. passim: Report on Able-Bodied Persons, p. 5. 
time the allowance system is believed to have "generally disappeared", 60 the justices remained an essential, if not the pivotal, part of the poor-relief system in Southern England.

The findings of a host of Select Committees, then, serve to support and confirm the more detailed view of local administration provided by the answers to the Royal Commission's rural queries. While this material precludes the precision in interpretation that can often be achieved through grass-roots research on original parish documents, these contemporary investigations probably represent the most decisive evidence available in connection with the role and influence of the large landowners in the pre-reform relief system. Any effort simply to correlate formal sessional decisions, especially those made at the county level, with actual administration in the parishes will fail to account for the highly personalized and diversified nature of magisterial policy-making under the Old Poor Law. ${ }^{61}$ The individual magnates holding sway in their own parishes without reference to any outside authority, the readiness of the laborers to resort to appeals to the local bench, and the overseers' tendency to anticipate magisterial judgements, particularly if threatened with an appearance before the justices, all constituted what may be termed the "invisible influence" of the magistrates in poor-relief affairs. Consequently, their authority in relief administration may not always be assessed in terms of the volume and scope of their formal decisions in sessions; indeed, the situation might arise where magisterial influence may actually appear to have been diminishing at the very time it was, in fact, increasing.

\section{IV}

A further question must be touched on here. It has recently been argued that the bulk of the justices came to adopt an unsympathetic posture in regard to the distribution of relief during the last decades of the Old Poor Law, the magisterial opponent of parochial attempts to reduce the rates being a "black sheep", defying "the consensus of the local landed magnates". ${ }^{62}$ In fact, from about 1795 onwards, the intervention of the magistracy was often systematically directed toward undermining parish economy measures, most notably in the rural parishes of Southern Eng-

60 Blaug, "The Poor Law Report Reexamined", p. 231.

61 For such an attempt, see M. Neuman, "Speenhamland in Berkshire", in: Comparative Development in Social Welfare, op. cit., pp. 107-10.

62 A. Brundage, "The Landed Interest and the New Poor Law: A Reply", in: English Historical Review, XC (1975), pp. 347-48; id., "The English Poor Law of 1834 and the Cohesion of Agricultural Society", in: Agricultural History, XLVIII (1974), pp. 407-08. 
land. ${ }^{63}$ Throughout the period before the reform of the Poor Laws in 1834, there was a general belief that only a parish free from the influence of the bench was able to reduce its rates to the level desired by most parishioners. ${ }^{64}$ Even when faced with declining rents in the years after Waterloo, the magistrates widely refrained from using their statutory power (under 50 Geo. III, c. 49) to reduce overseers' accounts. ${ }^{65}$ In later years the justices continued to be regarded as the main obstacle to efforts to economize. Nassau Senior, political economist and authority on the Poor Laws, informed Lord Brougham in 1832 that the magistrates as a group opposed all measures that would too severely constrict aid distribution and that he had "no hope of real improvements [i.e., a reduction in rates] while their power of interference remains undiminished". ${ }^{66}$ The Royal Commission's 1832 survey also shows unequivocal magisterial support for more generous relief on the eve of reform. The survey leaves the distinct sense that the justices almost invariably provided the barrier between the poor and the ratepayers in vestries who wished to scale down the rates. A simple quantification of the answers to question 44 of the rural queries confirms this impression. Question 44 asked: "What do you think would be the effect, immediate and ultimate, of making the decision of the Vestry or Select Vestry in matters of Relief final?" Of the 291 respondents who specifically addressed themselves to the issue of the probable level of relief expenditure under unrestricted vestry control, 272 believed that circumventing magisterial influence would mean a more stringent and economical distribution of aid, while only 10 maintained that relief would be dispensed more lavishly. ${ }^{67}$

There is the possibility that efforts to counter parish economy measures were the work of scattered "maverick JPs" rather than large segments of the magistracy. ${ }^{68}$ The chance of individual, lone "poor men's justices" disregarding the views of their colleagues while directing relief administration over wide areas must be taken seriously, if only because one of the

63 Report on Labourers' Wages, p. 6. See Rose, The English Poor Law, op. cit., p. 38; S. and B. Webb, The Old Poor Law, p. 166.

64 See, e.g., Report on the Poor Laws, 1817, p. 76; Report on Poor Rate Returns, 1823, p. 16.

65 Report on Poor Rate Returns, 1822, p. 7. See also Tate, The Parish Chest, op. cit., p. 17. 66 Nassau Senior to Lord Brougham, 14 September 1832, in: S. Leon Levy, Nassau W. Senior, 1790-1864 (Newton Abbot, 1970), Appendix X, p. 249. See also Richard Earle to Poor Law Commissioners, 25 June 1836, Second Annual Report, Appendix B, No 15, p. 386.

67 Nine asserted that there would be no change. Many more parishes than this actually answered the question, but their comments are irrelevant to the matter under consideration here.

68 Brundage, "The English Poor Law of 1834", loc. cit., p. 407; id., "A Reply", loc. cit., p. 348. 
assistants to the Royal Commission claimed this to be the case. ${ }^{69}$ The replies to the Commission's own survey, however, do not bear out this view. Of the 488 parishes reporting that the bench controlled relief administration, 328 gave some indication of whether the magistrates intervened singly or in groups. Of these, 302 reported interference by two or more justices, while only 26 noted a solitary justice intruding into relief affairs. Moreover, this latter group of magistrates appears to have intervened singly only in those areas under their direct social and economic influence, for in only two cases is there a clear example of a lone justice meddling in a parish outside his personal control. Consequently, it seems that when parochial authorities were interfered with, it was almost always the work of two or more magistrates sitting in petty sessions. There is, in any event, no evidence here of a handful of actively compassionate or fearful justices frustrating large numbers of non-interventionist magistrates, who wished to support economy measures. The interference of the bench was simply too common a feature of parochial administration, too widespread, and its tendency too unmistakable to accept the validity of such a notion.

One factor that may lead to a supposition of magisterial support for a more stringent distribution of aid was the reduction in minimum bread rations established by quarter-sessional scales during the post-Napoleonic period. ${ }^{70}$ In evaluating the significance of this decline it must be stressed once again thatnformal bread scales do not adequately reflect the ad hoc, localized nature of Poor Law administration during the period before 1834 . Many justices considered the quarter sessions to be an inappropriate body for the formulation of Poor Law policy because of the special concerns of the landlords in each of the parishes under their local jurisdiction. ${ }^{71}$ In a relief system notorious for its heterogeneity, it is not surprising that the qualities of order, universality and precision associated with the word Speenhamland were rarely found. The point is that bread scales do not always provide an accurate view of practice at local, parish level. ${ }^{72}$ In addition, the bread scales were becoming less important for the support of the poor just at the time scales were declining in generosity. High bread prices, the chief concern of relief authorities in the first two decades of the nineteenth century, forced attention to the need to ensure an adequate wage for subsistence. By the 1820's, however, prices were lower, which

69 The Poor Law Report of 1834, op. cit., pp. 229-30. Also quoted in Brundage, "A Reply", p. 348.

70 See J. L. and B. Hammond, The Village Labourer, 1760-1832 (London, 1912), pp. 184-85; Blaug, "The Myth of the Old Poor Law", loc. cit., pp. 161-62; Brundage, "A Reply", p. 347.

${ }_{71}$ Answers to Rural Queries, Pt IV, q. 44, passim.

${ }^{72}$ See Neuman, "Speenhamland in Berkshire", loc. cit., pp. 107-08. 
rendered the scale allowance less critical (except for laborers with large families), while the problems of structural and seasonal unemployment were more strongly felt, requiring more direct means of magisterial intervention than the setting of bread scales. ${ }^{73}$

Still, there is no doubt that official relief scales published after 1815 were not as generous as the original Speenhamland model. It would be foolhardy, however, simply to attribute this fact to a consensus among the magistrates that economy should be pursued at the poor's expense. There are strong indications that it was the growing dissatisfaction of the tenantry and the small ratepayers that forced the justices into a more careful distribution of aid. In attempting to control the mechanism of relief dispensation, the Southern magistrates often encountered after 1813 the sullen opposition of tenant and freehold farmers facing an increasing rate burden and a sharp decline in the prices they received for their produce. ${ }^{74}$ As the Rev. Joseph Bosworth of Buckinghamshire told a Select Committee in 1828. "The minimum [allowance] of the magistrates is the maximum of the farmers." 75 Throughout the 1820's, Select Committees were inundated with objections from parochial authorities as to the justices' relief policies, while later the 1832 survey more systematically confirmed widespread dissatisfaction with magisterial administration, the Royal Commission receiving, according to Nassau Senior, "many complaints of the conduct of magistrates". ${ }^{76}$

The almost invariable ratepayer predilection, at least as it is expressed in the Parliamentary Papers, was to differentiate between the "deserving" and "undeserving" poor when distributing the rates. ${ }^{77}$ Any overt deviation from such a principle was almost certain to elicit a stream of complaints from ratepayers that the appeal procedure operated as "a premium for profligacy" and resulted in the moral degeneration of the laborers. ${ }^{78}$ What

73 Oxley, Poor Relief, pp. 116-17; Baugh, "The Cost of Poor Relief”, loc. cit., pp. 59, 64.

74 Report on Labourers' Wages, p. 40.

75 Report on Able-Bodied Persons, p. 38.

76 Nassau Senior to Lord Brougham, 14 September 1832, loc. cit., p. 247; Report on Poor Rate Returns, 1822 , pp. $28-30 ; 1824$, p. $25 ; 1825$, p. 19; 1826, pp. 17-18; Minutes of the Lords Committee, 1817, p. 74; Richard Hall to Poor Law Commissioners, 10 July 1835, First Annual Report, Appendix B, No 4, p. 129. See also The Poor Law Report of 1834, p. 240.

${ }^{77}$ See Minutes of the Lords Committee, 1817, pp. 35-36; Report on the Poor Laws, 1817, p. 109; Report on Poor Rate Returns, 1824, p. 17; 1825, p. 18; J. P. Huzel, "Malthus, the Poor Law, and Population in Early Nineteenth-Century England", in: Economic History Review, Second Series, XXII (1969), p. 446.

78 See Board of Agriculture, The Agricultural State of the Kingdom (New York, 1970; first ed. 1816), p. 25; Report on Poor Rate Returns, 1822, pp. 28-30; 1824, p. 25; 1825, p. $19 ; 1826$, pp. 17-18. 
the ratepayers failed or refused to appreciate was that when the poor appealed directly to the local magistrates, their options in ordering relief became increasingly limited as conditions worsened for the laborers at the same time the quarter sessions or the parochial authorities reduced relief to the subsistence level. ${ }^{79}$ The result was that the magistrates might have been willing to sanction reductions in aid to the point where it provided only what was absolutely required for subsistence ${ }^{80}$ But when the laborers were threatened with extreme want, the justices very often showed themselves resolved to thwart parochial efforts to drive down relief even further. The diminution of relief in the post-war period thus represented what was seen as a necessary adjustment in magisterial policy rather than a move to lend full support to the economy measures of hard-pressed ratepayers. This explains the apparent contradiction between declining relief scales after 1815 and the evidence of parliamentary investigations and official surveys that the local justices nearly always intervened in favor of the poor, and did so in strength at times of deteriorating conditions for the laborers. In short, relief allotments could reach the level where the community leaders felt bound to oppose the economic interests of their rate-paying constituents.

The degree of dissatisfaction that such a policy could generate made it all the more imperative that the justices retain unfettered control of administration. The dramatic change in relief practices in many parishes following the reform of the Poor Laws in 1834 attests to the distinct and prevalent desire of ratepayers to run their affairs according to what they conceived to be their own best interests. Although themselves prominent advocates of a more stringent administration of relief, the Poor Law Commissioners appointed under the amending act were horrified to find occurrences of a "precipitate and violent change [in aid dispensation] made by some of the overseers on their own responsibility" during the transition in modes of relief administration. "[We] found", the Commissioners stated in their First Annual Report, "that a conception had been extensively propagated amongst the overseers in the rural parishes [. . .]; that by the operation of the Poor Law Amendment Act they were entirely released from the control of the magistrates. The consequences [...] were represented to be, that

79 Minutes of the Lords Committee, 1817, pp. 25, 97; Memorial of the Magistrates of the County of Suffolk, respecting Poor Rates, n.d., Report on the Poor Laws, 1817, Appendix H, p. 167; Report on Labourers' Wages, p. 35.

80 Report on Labourers' Wages, p. 40. 
those dependent on parochial relief were harshly treated, and subjected to privations unwarranted by the Legislature." The Commissioners promptly issued a circular letter setting forth the powers of the bench until the new boards of guardians could be established. But this merely had the effect of opening the entire question of the magistracy's status under the new law, leading the Commissioners into "a widely extended correspondence, in answer to solicitations from all parts of the country for more detailed explanations". 81

A closer investigation of developments in a single county at this time makes more cogent the Commissioners' generalizations about this "ratepayers' revolt". Bedfordshire has been selected for such an examination because its relief expenditure was sufficiently burdensome to concern ratepayers, while its level of magisterial interference had not been so overbearing as to have created an unusual degree of conflict between magistrates and ratepayers. ${ }^{82}$ Despite this latter consideration, in Bedfordshire, too, the passage of the new law was the signal for overseers and vestries all over the county to review and sharply cut the relief rolls. ${ }^{83}$ George Livins, a county magistrate and a director of the Bedford House of Industry, reported that "in many Parishes, the Overseers have already begun to act, on the improved System - in some indeed rather hastily \& indiscreetly". ${ }^{84}$ An even more prominent justice, Lord Charles Russell, wrote to one of the Poor Law Commissioners to complain of the new-found independence of the parochial officers and the consequent threat to the poor: "an opinion has become prevalent amongst them [the overseers], that magistrates have no longer any control over them: this day, sixty paupers of one parish appealed against the overseer on account of insufficiency of relief." 85

Being subjected to this challenge to their authority because of the ambiguities of their legal status, the Bedfordshire magistrates' immediate apprehension was for the maintenance of social peace in the county. The Amphill petty sessions told the Commissioners that if the reformed system actually prevented them from ordering outdoor relief, as it was generally supposed it did, "the result anticipated in this Agricultural County bears

81 For all of above, First Annual Report, pp. 4-6.

82 See p. 383.

83 See, e.g., Luton Union: William Rudd, Overseer, to Poor Law Commissioners, n.d. [c. 24 September 1834], Ministry of Health Papers 12/96, Public Record Office; Biggleswade Union: F. Smith, Assistant Overseer, to id., 4 March 1835, MH 12/55; Amphill Union: George Smith to id., 25 September 1834, MH 12/1.

84 Bedford Union: George P. Livins to the Commissioners, 24 October 1834, MH 12/21.

85 Woburn Union: Lord Charles Russell to T. F. Lewis, 21 November 1834, MH 12/126. 
a most alarming aspect". ${ }^{86}$ Urgent pleas for a re-assertion of magisterial authority in relief affairs even came from the all-powerful Russell family in the Woburn district, where they were confronted with a chronic problem of surplus labor. Lord Charles Russell was extremely worried about parochial cuts in relief allotments, because the local magistrates did not feel able "to enforce, or in any way to protect the paupers". ${ }^{87}$ Lord Tavistock shared his concern and berated their brother, Lord John Russell, the Home Secretary, for introducing the act into the county with winter approaching and without the proper administrative safeguards for the poor. Tavistock's principal complaint was that the new law had momentarily swept away all higher authority in relief administration. ${ }^{88}$ Russell at the Home Office reacted immediately by ordering the Poor Law Commissioners to send down one of their assistants, and D. G. Adey was dispatched at once. ${ }^{89}$ It seems, however, that this provided little comfort for the frantic landowners, for Adey reported back that he was powerless to amend the situation: "I had a long interview with Lord C. Russell, Col. Seymour and Mr. Bennett, the Duke of Bedford's Steward, on my arrival here [Woburn]. What they sent for an Assist. Commissioner for I can hardly understand. Their questions were more magisterial than poor law questions. Their chief difficulty seemed to be how they were to prevent a congregation of unemployed Labourers." 90

Adey's comments reveal a startling ignorance of the bench's persistent use of the Poor Laws to cope with unemployment and thus ensure the security of the social order. What he did not fully understand was that for country gentlemen faced with large numbers of discontented laborers there was no such distinction between poor-law and magisterial questions. The Bedfordshire landlords had sent for an Assistant Commissioner precisely because parochial officers throughout the county were extensively, and in many cases effectively, defying the magistrates' accustomed authority in directing relief administration, which had been used to prevent "congregations of unemployed Labourers". The crucial point here is that the justices - and as the difficulties of the Poor Law Commissioners make

${ }^{86}$ Amphill Union: Amphill Petty Sessions (signed by 5 JPs) to the Commissioners, 11 September 1834, MH 12/1. See also Woburn Union: John Green to id., 30 September 1834, MH 12/126; Amphill Union: Rev. James Beard, JP, to id., 2 May 1835, MH 12/1. 87 Woburn Union: Russell to Lewis, 21 November 1834.

88 Bedford Union: Lord Tavistock to Lord John Russell, 10 November 1834, MH 12/21. As we have seen, the government had not in fact prematurely introduced the act into Bedfordshire; the overseers had implemented a harsher policy on their own initiative.

89 Bedford Union: Lord John Russell to Edwin Chadwick, 12 November 1834, MH $12 / 21$.

${ }^{90}$ D. G. Adey to the Commissioners, 14 November 1834, MH 32/5. 
clear, this pertains not only to those in Bedfordshire - were apparently unable to re-assert their supremacy in relief affairs through means of their social and economic influence once their legal authority had been called into question. Under the Old Poor Law, the "traditional legitimacy" of the landowners' authority, so evident in many aspects of country life, was widely converted under the stress of adverse economic conditions into a "rational-legal legitimacy", which relied heavily upon institutional rather than personal sanctions for its potency. The Rev. Anthony Collett, JP of Suffolk, touched on this when he told an 1824 Select Committee that his efforts to compel his own tenants to conduct the relief system in the way that he thought best required "a degree of authority which nothing but the power I am invested with as a magistrate could accomplish".91 The landlords' domination of county politics and the usual willingness of the tenantry and freeholders to accept the judgement of the proprietors in political matters should not lead us to assume similar acquiescence when landlord power was applied in such a way as to cause the farmers to doubt whether that power was being used in their best interests. Questions that most closely concerned their lives, such as the burden of the rates, could elicit a surprising degree of independence. ${ }^{92}$

\section{VI}

Conflict between ratepayer and magistrate primarily arose because each had contradictory views on the purposes of poor relief and the imperatives of social and economic life. For rate-paying occupiers and their parochial officers - mostly tenant farmers and small owners in the rural areas - the principal priority was to minimize all demands on their limited capital assets. Their central place in a highly developed market economy ensured that economic rationalization, having one of its chief expressions in a "cult of severity" toward the poor, would shape many of their attitudes to relief administration. ${ }^{93}$ This was particularly so in Southern England after 1813, when the sharp fall in the price of grain sent marginal producers to the wall and increased economic pressures on the survivors. On the other hand, while falling prices and rising rates might eventually lead to a reduction in rents, the large landowners, with their greater resources and access to credit, were far more insulated from the vicissitudes of the market. The rentier magistracy, consequently, were not as necessarily or obviously in

91 Report on Labourers' Wages, p. 57.

92 See Report on Able-Bodied Persons, p. 40.

93 Kerr, "The Dorset Agricultural Labourer", loc. cit., p. 170; Neuman, "Speenhamland in Berkshire", pp. 114-15. 
the business of making profits. For the magistrate, the gentleman, land not only represented income but conferred status and "influence" and a place at the top of the rural hierarchy. And it was this hierarchy and the social accountability that maintained the "chain of connexion" between its ranks that the parsimony of the ratepayers seemed to threaten. The resultant efforts to allay such a threat help to reveal a prevalent feeling among the magistracy as a group that the vestries and parish officers could not be trusted to abstain from pursuing their own "selfish designs" in administering the rates, and that only the bench stood between a harmonious order and "servile war" and "agrarian law".

Considering the marked and widespread efforts of magistrates in the most heavily distressed areas to provide a guarantee against unrestrained economic interest, there is a strong temptation to conclude that the large landowners readily accepted their paternal responsibilities to protect the poor, at least in regard to their administration of the relief system. The reality was far more complicated. The gentry's complicity in the brutal enforcement of the game laws, the destruction of housing for the creation of "close" parishes, and the economic rationalization of estate management should warn us against too readily ascribing to them a deep-seated sympathy for the poor. There are indications that some magistrates intervened on behalf of the poor with extreme reluctance, only the pressure of demand for amelioration prodding them to action. ${ }^{94}$ It is also probable that after the Napoleonic Wars the justices were somewhat more willing to consider the interests of the ratepayers in distributing aid than they had been previously. Even the Bedfordshire magistrates, who were so concerned for the relief of the laborers in 1834, appear to have had the ulterior motive of protecting the social order from which they derived such a disproportionate benefit. In these instances, at least, unalloyed benevolence and adherence to an aristocratic ideal were latent motives at best. The thorny question of "close" parishes also muddies the water. Magistrates residing in such areas were often protected from the financial burdens arising from their relief orders; at the same time, some of these justices may have been motivated by a desire to ensure, for the sake of their more substantial tenants, the support of an adequate labor supply at the expense of smaller ratepayers in populous neighboring parishes. ${ }^{95}$

94 See, e.g., Memorial of the Magistrates of the County of Suffolk, loc. cit., p. 167.

95 The difficulties here are not as great as might be supposed. B. A. Holderness has shown that the system of "open" and "close" parishes was only of "minor importance" in Southern and Eastern England, the area with which we are most concerned. The system was most common in the North-East Midlands, West Norfolk, and the East Riding. In addition, it is significant that the trend of increase in Poor Law expenditure bears no 
Yet the rhetoric often employed by the gentry to justify and define their relief activities as magistrates constituted an identifiable "morality" that was incompatible with the pursuit of self-interest or the mere safeguarding of class power. In 1832 justices from all over the country made known to the Royal Commission their deep indignation at the injustice and "oppression" that ratepayers in vestries were wont to mete out to the poor. ${ }^{96}$ Faced with this challenge to the proper ordering of society, which necessarily led on to "the abstraction [sic] of that feeling which used to bind the servant to his master", magistrates voiced their intention to assume their roles as the poor's "guardians", "advocates" and "natural protectors". ${ }^{97}$ Some even insisted that such a policy was something more than a matter of prudence, that the poor had a right to protection and maintenance, and that the privilege of property conferred an obligation on the landlord to uphold that right. ${ }^{98}$

These articulations of an aristocratic, paternalist ideal should not be dismissed as the empty expressions of privileged men who were only prepared to make mere ritualized gestures toward a justice they conceded. Such slogans prescribed specific modes of behavior and provided clear guidance and sanctions for the magistrates when called upon to "mediate" between the ratepayers and the poor. Crisis conditions, especially, offered ample temptation for the justices to revert to the paternalist ideal, for it was then that the need to re-affirm the older, more stable order became all the more crucial. Certainly an emergency - and the whole of our period may be seen in such terms - could be expected to call forth among conservative community leaders a willingness to utilize traditional social institutions like the Poor Laws in such a way as to preserve the credibility of their rule. ${ }^{99}$ Quite apart from the acute problems confronting authority in the South and East, the characteristics of these regions also encouraged greater attachment to older ideals of social responsibility. The comparative dearth of freehold tenure and smallholdings, the small scale of domestic industry, and the prevalence of traditional, nucleated villages in these areas all

relationship to the prevalence of the system, both "open" and "close" parishes experiencing the same pressure on the rates in the nineteenth century. "Open' and 'Close' Parishes in England in the Eighteenth and Nineteenth Centuries", in: Agricultural History Review, XX (1972), pp. 129, 132, 134, 136, 137-38.

96 See, e.g., Answers to Rural Queries, Pt IV, pp. 7d, 16d, 100d, 147d, 165d, 198d, 219d, 236d, $241 \mathrm{~d}, 297 \mathrm{~d}, 320 \mathrm{~d}, 338 \mathrm{~d}, 349 \mathrm{~d}, 378 \mathrm{~d}, 396 \mathrm{~d}, 434 \mathrm{~d}, 440 \mathrm{~d}, 460 \mathrm{~d}, 469 \mathrm{~d}, 487 \mathrm{~d}, 548 \mathrm{~d}, 566 \mathrm{~d}$. 97 Ibid., pp. 100d, 178d, 253d, 413d, 477d, 586d.

98 See ibid., pp. 165d, 219d. Charles Savill Onley, JP, of Stisted Hall, Essex, claimed that "this opinion is corroborated by those of many respectable Magistrates with whom I have conversed on the subject". Ibid., p. 187d.

99 This is not to suggest that they did not believe their own rhetoric. See Thompson. Whigs and Hunters, op. cit., p. 263. 
operated toward the preservation of communities where social ranks were fairly stable and distinct, and custom relatively rigid. ${ }^{100}$

While at all levels of the community this contributed to heightened appreciation of the role of reciprocal obligations in rural relationships, customary usages pertaining to subsistence and the rhetoric of paternalism were made even more generally binding when the poor themselves adopted them as a part of their rights and heritage. The distribution of the poor rates was popularly conceived to be the means by which, in the last extremity, the local society discharged its obligation to support all of its members. ${ }^{101}$ Parochial authorities persistently complained that the laborers regarded relief as their fair share of the social dividend, a Select Committee in 1824 noting that on the justices' allowance "the labourer relies as a right; and when he receives less, he makes an angry appeal to a Magistrate, not as a petitioner for charity, but as a claimant for justice" ${ }_{102}$ At least some part of the aristocratic ideology, therefore, had a real existence in expectations of support among the poor and in their access to an appellate procedure that allowed them to make direct appeals to those most clearly pledged to notions of social accountability. Within this context, the authorities often had little choice but to conform to the roles demanded of them as community leaders. ${ }^{103}$ Practical weight was added to these expectations by the laborers' readiness to resort to violence in order to obtain their rights in the poor's rate. ${ }^{104}$ Even the safety valve of the appellate procedure could at times assume a sufficiently menacing aspect. ${ }^{105}$ And since the bench had to deal in some way with all complainant initiatives, no resident justice was entirely free to disengage himself from parish affairs and thereby limit the laborers' activities to "negotiating" with the overseers for adequate aid. In this way, the economic pressures on the laborers helped to transform the magistrates' administration of the Poor Laws from a part of the "theatre of the great" into an administration which enjoined close attention to the operation of a social institution of considerable scope and significance in the community.

100 A. D. Gilbert, Religion and Society in Industrial England (London, 1976), pp. 98-99.

101 S. and B. Webb, The Old Poor Law, pp. 181-82.

102 Report on Labourers' Wages, p. 7. See also ibid., p. 48; Report on Able-Bodied Persons, p. 27.

${ }^{103}$ See Minutes of the Lords Committee, 1817, p. 19; Report on the Poor Laws, 1817, p. 90; Report on Labourers' Wages, p. 34.

104 A. J. Peacock, "Village Radicalism in East Anglia, 1800-50", in: Dunbabin, Rural Discontent, op. cit., p. 36.

105 See Bedford Union: Livins to the Commissioners, 24 October 1834, for a description of prompt magisterial action against local overseers when more than 200 laborers appealed to the bench en masse. 
The early nineteenth century, then, saw an increased need to rehabilitate and glorify the kind of face-to-face relationships characteristic of a method of social control based on the obedience of the poor and the benevolent overlordship of the rulers. Even though the bulk of the laborers did not encounter the gentry as employers, the landlords' emerging control of relief administration made them seem more directly responsible for the laborers' conditions of life. For this reason, in part, personal interaction between magistrate and laborer became one of the rural flash points in the troubled years of the early nineteenth century. When the indignities of day-labor, of prolonged dependence on the ratepayers, of encroachments upon customary rights became too much for the laborers to bear, the gentry also shared in suffering popular reprisals, the targets of which were largely selected on the basis of perceived responsibility for the degradation of the poor. ${ }^{106}$ Indeed, it was the highly personal, individualized nature of the laborers' animosities toward some of the large landowners that made the rural riots of 1830-31 seem so frightening, even novel. ${ }^{107}$ But so far from reflecting the withdrawal and isolation of the landlords or their adherence to the tenets of laissez faire, such breakdowns in social cohesion may actually have been fueled by greater individual activism on the part of some of the gentry and their trumpeting of a residual paternalist ideal. Even though such an ideal was predicated on order and subordination, re-affirming its other imperatives could only become an additional source of discontent whenever and wherever authority failed to conform to its proper role.

This is a salutary reminder that cultural models such as social accountability become increasingly removed from realities during periods of rapid, sustained and fundamental change. ${ }^{108}$ The prevalence of anonymous violence and major disturbances in early-nineteenth-century rural life reveals the extent to which the large landowners actually failed to provide the minimal requirements of the laborers. It must be stressed, nonetheless, that the ideal of an organic society continued to exert a hold on the minds of those with the responsibility of governing rural England. This does not mean that the material and intellectual infringements of the wider society were not altering rural social relations, or that the gentry

106 Hobsbawm and Rudé, Captain Swing, pp. 184-85. See also D. E. Williams, "Were 'Hunger' Rioters Really Hungry? Some Demographic Evidence”, in: Past \& Present, No 71 (1976), p. 74.

107 See Lord Melbourne to Lord Grey, 29 October 1831, Grey Papers, Box 41/2, University of Durham.

108 E. J. Hobsbawm, "From Social History to the History of Society", in: Daedalus, C (1971), p. 38 . 
remained as concerned with social responsibilities as their counterparts in the seventeenth century. It does mean, however, that prescriptions of "goodness" continued to exert a considerable residual influence on gentry behavior, if only because the realities of parochial life and opinion discouraged overt denials of social accountability. Regardless of the part the landlords' own estate policies had played in the break-up of cherished institutions, they clung to an image of themselves as the protectors of the poor, charging their tenants and the freeholders with being insensitive to the plight of the laborers. ${ }^{109}$ Even in those cases where such an image could only have been a delusion on the part of the landowners, at least the re-assertion of appropriate role models continued to be seen as essential for the justification of the hierarchy. In other cases, the expression of proper values and modes of behavior went beyond a mere habit of social thinking and gave practical import to ideas of paternalism. The clash between the divergent "moralities" and priorities of the magistrates and ratepayers indicates how tenaciously much of the gentry held to the catchphrases and forms of a paternalistic society in dealing with problems of poverty. Responding to communal expectations of support, the greater part of the magistracy in Southern England chose, for whatever reasons or however reluctantly, to operate firmly within a tradition of legitimizing slogans and procedures. As a result, right up to the reform of the Poor Laws in 1834, the large proprietors may be seen to have had a prominent part in efforts to alleviate poverty, rather than to have been removed from the periodic crises that swept rural England after 1795.

109 See E. Richards, "“Captain Swing" in the West Midlands", in: International Review of Social History, XIX (1974), pp. 87-89. 